\title{
TA'LÎL AL-AHKÂM DARI MASA RASULULLAH HINGGA MASA ULAMA USHÛL
}

\author{
Nurlailatul Musyafaah Univeritas Islam Negeri Sunan \\ shafaadesign@yahoo.com Ampel Jl. A. Ayni 117 Surabaya
}

\begin{abstract}
Ta'lîl al-ahkâm is explaining by finding the legal reason. At the time of the Prophet, ta'lîl was contained in the Qur'an and hadith, among them: 1.' Illat was embodied with the character of law, 2. Stating the legal position with its reason and historical background, 3. Explaining command accompanied by tafdhill, 4. Explaining law with its reason marked with the letter of ta'tîl, 5. Explaining law and its explanation about the benefit or in otherwise. The methods of ta'îl al-ahkâm at the time of companion: 1 . Elimination of the penalty for refusing mafsadah, 2. Law is changed because its legal reason has been lost. 3. Not carrying out the command of Allah and His Messenger for the reason of mafsadah if the work is still performed, 4. Assigning the unassigned law at the time of Prophet for the sake of refusing mafsadah, 5 . Doing something which was not done at the time of the Prophet for the reason of gaining benefit, 6. Establishing law based on the text without searching the illah. The methods of ta'îl alahkâm at the period of tâbi'în and tâbi' tâbiînn: 1. Advancing benefit, the law contained in the textis absolute or contrary to the public welfare, 2. Using the method of maslahah mursalah. 3. Leaving a permissible act by the reason of mafsadah. The methods of ta'îl al-ahkâm in the period of Muslim scholars of ushûl: with text, ijmâ', and al-sabr wa al-taqsîm.
\end{abstract}

Keywords: Ta'lîl al-ahkâm, period of the Messenger, period of the Muslim scholars of ushûl.

Abstrak: Ta'î̀ al-ahkâmadalah menjelaskan dancara menemukan ilat hukum. Pada masa Rasulullah, ta'lîl terdapat pada al-Qur'an dan hadis, di antaranya; 1. llat menyatu dengan sifat hukum, 2. Menyebutkan hukum beserta sebabnya. 3. Menjelaskan perintah diiringi dengan lafadz tafdhîl, 4 . Menjelaskan hukum beserta ilatnya yang ditandai dengan huruf ta'lîl, 5 . Menjelaskan hukum disertai dengan penjelasan maslahatnya, atau sebaliknya. Metode ta'îil al-ahkâm pada masa Sahabat: 1. Meniadakan hukuman karena alasan menolak mafsadah, 2. Hukum menjadi berubah, karena ilatnya telah hilang, 3. Tidak melaksanakan perintah Allah dan RasulNya, karena adanya mafsadah apabila pekerjaan tersebut tetap dilaksanakan. 4. Menetapkan hukum yang belum ditetapkan Rasulullah demi menolak mafsadah, 5. Mengerjakan pekerjaan yang tidak dikerjakan 
pada masa Rasulullah, dengan alasan kebaikan, 6. Menetapkan hukum berdasarkan nas yang ada tanpa mencari ilat hukum.Metode ta'îl alahkâm pada masa Tâbi'în dan Tâbi' Tâbi'în: 1. Mendahuluan maslahat, jika hukum yang terkandung dalam nas bersifat mutlak atau umum bertentangan dengan kemaslahatan, 2. Menggunakan metode maslahah mursalah. 3. Meninggalkan pekerjaan yang mubah atau sunnah, karena jika dikerjakan akan mendatangkan mafsadah. Metode ta'lîl al-ahkâm pada Masa Ulama Ushûl: Dengan nash, ijma', dan al-sabr wa al-taqsîm.

Kata Kunci: Ta'lîlal-ahkâm, Masa Rasulullah, masa Ulama Ushûl.

\section{Pendahuluan}

Agama Islam berkewajiban mengajarkan syariatnya kepada umatnya. Pada masa Rasulullah, syariat tersebut diwahyukan langsung kepada Rasulullah, sehingga umat Islam bisa bertanya langsung kepada beliau. Setelah Rasulullah wafat, dan penyebaran wilayah Islam semakin meluas, semakin banyak orang yang masuk Islam, dan semakin banyak pula persoalan baru yang muncul, yang dibutuhkan penyelesaian hukumnya, karena itu, muncul ijtihad sebagai cara untuk memecahkan problematika tersebut.

Ijitihad adalah mengerahkan segala upaya untuk istinbâth hukum syar'i yang terkandung di dalam ungkapan nash, isyarat, dan artinya; untuk itu diperlukan mencari ilat hukum, jika belum disebutkan ilat dalam nas. ${ }^{1}$ Untuk Pencarian ilat hukum itu, dibutuhkan ta'lîl al-ahkâm.

Secara bahasa, ta'lîl merupakan masdar dari 'allala. Dikatakan "allala al-rajul" berarti seorang lelaki menyirami sesuatu, siraman demi siraman, atau "'allala al-rajul al-thamrah", berarti seorang lelaki memetik buah, satu demi satu. Secara istilah, "allala al-syay" berarti menjelaskan ilat sesuatu dan menetapkannya dengan berdasarkan dalil.

Menurut Syalabi, ta'lîl al-ahkâm adalah menjelaskan dan cara menemukan ilat hukum. Ta'îl berguna untuk ijtihad dengan menggunakan metode qiyâs, istishlâh, mashlahah mursalah, atau untuk menjelaskan hikmah. ${ }^{2}$

\footnotetext{
${ }^{1}$ Muhammad Musthafa Syalabi, Ta'lîl al-Ahkâm (Beirut: Dar al-Nahdah al-'Arabiyyah, 1981), 12.

${ }^{2}$ Ibid.
} 
Dalam sejarahnya, ta'lîl al-ahkâm memiliki metode yang bervariasi dalam setiap masa. Berikut dibahas tentang metode ta'lîl alahkâm dari semenjak masa Rasulullah hingga setelah masa ulama ushûl.

\section{Metode Ta'lîl pada Masa Rasulullah}

Ta'lîl pada masa Rasulullah, terdapat pada al-Qur'an dan hadis, dengan metode yang bervariasi.

a. Metode al-Qur'an dalam ta'lîl al-ahkâm

Ta'lîl hukum syar'i di dalam al-Qur'an menggunakan metode yang variatif, sehingga tidak membosankan dan tidak menjemukan bagi pembacanya. Di antara metode ta'lîl al-ahkâm dalam al-Qur'an adalah:

1) Ilat tersebut menyatu dengan sifat hukum, seperti ayat tentang hukuman bagi pezina, ${ }^{3}$ hukuman potong tangan bagi pencuri, ${ }^{4}$ diperbolehkannya salat qasar bagi musafir, ${ }^{5}$ dan larangan masuk masjid al-harâm bagi orang musyrik. ${ }^{6}$

2) Menyebutkan hukum beserta sebabnya, yaitu disertai dengan huruf sababiyyah sebelum atau sesudah penjelasan hukum, seperti ayat tentang diperbolehkan berperang bagi orang yang teraniaya dalm AlQur'an, 22: 39:

Telah diizinkan (berperang) bagi orang yang diperangi, karena sesungguhnya mereka telah dianiaya. dan sesungguhnya Allah, benar-benar Maha Kuasa menolong mereka itu.

3) Menjelaskan perintah diiringi dengan sifat athhar (lebih bersih) atau azkâ (lebih suci), seperti ayat tentang menjaga pandangan antara lelaki dan perempuan, yang menggunakan kalimat azkâ dalam alQur'an 24:30:

Katakanlah kepada lelaki yang beriman: "Hendaklah mereka menahan pandangannya, dan memelihara kemaluannya; yang demikian itu adalah lebih suci bagi mereka".

Begitu juga ayat tentang hijab yang menggunakan kalimat athhar dalam al-Qur'an, 33: 53.:

\footnotetext{
${ }^{3} \mathrm{Al}-\mathrm{Qur}$ 'an, 24:2.

${ }^{4} \mathrm{Al}$-Qur'an, 5: 38.

${ }^{5}$ Al-Qur'an, 3: 101.

${ }^{6}$ Al-Qur'an, 9: 28.
} 
Dan apabila kamu meminta sesuatu (keperluan) kepada mereka (isteri Nabi), maka mintalah dari belakang tabir. Cara yang demikian itu lebih suci bagi hatimu dan hati mereka.

4) Menjelaskan hukum beserta ilatnya yang ditandai dengan huruf ta'lîl,

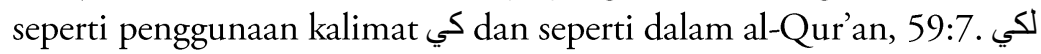

Apa saja harta rampasan (fai) yang diberikan Allah kepada

RasulNya (dari harta benda) yang berasal dari penduduk kota, maka adalah untuk Allah, untuk rasul, kaum kerabat, anak yatim, orang miskin dan orang yang dalam perjalanan, supaya harta itu jangan beredar di antara orang-orang kaya saja di antara kamu.

5) Menyuruh mengerjakan hukum disertai dengan penjelasan maslahatnya, atau sebaliknya, melarang sesuatu dan menjelaskan mafsadahnya, ${ }^{7}$ seperti ayat tentang pengharaman khamar dalam alQur'an, 5:90-91:

Hai orang yang beriman, sesungguhnya (meminum) khamar, berjudi, (berkorban untuk) berhala, mengundi nasib dengan panah, adalah termasuk perbuatan syaitan, maka jauhilah perbuatan itu agar kamu mendapat keberuntungan. Sesungguhnya syaitan itu bermaksud hendak menimbulkan permusuhan dan kebencian di antara kamu lantaran (meminum) khamar dan berjudi itu, dan menghalangi kamu dari mengingat Allah dan sembahyang; Maka berhentilah kamu (dari mengerjakan pekerjaan itu).

b. Metode Sunnah dalam ta'lîl al-ahkâm

Muhammad sebagai seorang Nabi, berkewajiban menyampaikan risalah Islam kepada ummatnya dengan penjelasan yang mudah difahami. Dalam menyampaikan ajaran Islam, Rasulullah menjelaskan hukum dengam metode yang variatif, agar ummatnya tidak jenuh, maka dalam menjelaskan perintah dan larangan suatu hukum, seringkali beliau menyertakan dalam sabdanya penjelasan tentang ilat hukum tersebut. Metode ta'lîl al-ahkâm

\footnotetext{
${ }^{7}$ Muhammad Mustafa Syalabi, Ta'lîl al-Ahkâm,14-15.
} 
sunnah Rasulullah, disesuaikan dengan kondisi sahabat ketika beliau menyampaikan sabdanya. ${ }^{8}$

Dalam hal ini, banyak sekali riwayat yang dapat dijadikan contoh mengenai hal tersebut, salah satunya adalah ketika Rasulullah menjelaskan tentang alasan tidak keluarnya beliau ke masjid untuk salat malam berjamaah:

Diriwayatkan dari Aisyah, bahwa Rasulullah saw salat malam di kamarnya yang berdinding pendek, para sahabat pun bisa melihat sosok Rasulullah saw, maka mereka ikut berdiri melaksanakan salat bersama beliau. Ketika pagi, mereka ramai membicarakan hal tersebut, maka Rasulullah salat kembali pada malam yang kedua, dan para sahabat pun mengikuti salat Rasulullah. Mereka melakukan hal tersebut sebanyak dua atau tiga malam, hingga setelah itu Rasulullah berdiam dan tidak keluar, maka ketika pagi, para sahabat menanyakan hal tersebut, Rasulullah menjawab: "Sesungguhnya aku khawatir, jika salat malam hukumnya menjadi wajib bagi kalian."

Hadis tersebut menandakan adanya anjuran salat malam, dan boleh dilakukan secara berjama'ah. Beliau menegaskan bahwa salat malam secara berjamaah hukumnya tidak wajib, dikhawatirkan jika hukumnya wajib, maka akan menyulitkan kaum muslimin, karena itu beliau menjelaskan dengan perbuatannya meninggalkan salat setelah malam ketiga. Perbuatan dan ucapan Rasulullah tersebut secara tidak langsung menjelaskan ilat tentang tidak diwajibkannya salat malam secara berjamaah. ${ }^{10}$

Rasulullah juga menjelaskan jenis perdarahan pervaginam yang tiada henti keluar dari Fatimah bint Abi Hubaish, sehingga ia meninggalkan salat karena menganggapnya sebagai darah haid. Ketika ia mengadukan kasusnya kepada Rasulullah, maka Rasulullah bersabda:

"Tidak, itu adalah irq dan bukan haid"11

Penjelasan tersebut menandakan adanya perbedaan darah yang biasa keluar normal, yaitu haid dan nifas, dan darah yang keluar

\footnotetext{
${ }^{8}$ Ibid., 23.

${ }^{9}$ Al-Bukhari, Shahîh, hadis no. 687 dalam CD al-Kutub al-Tis'ah. Hadis shahîh.

${ }^{10}$ Muhammad Musthafa Syalabi, Ta'lîl al-Ahkâm, 25.

${ }^{11}$ Al-Bukhari, Shahîh, hadis no. 221 dalam CD al-Kutub al-Tis'ah. Hadis adalah hadis shahîh.
} 
darah tidak normal, berarti bukan haid dan nifas, dengan implikasi hukum ibadah yang berbeda, akibat perbedaan jenis perdarahan tersebut. $^{12}$

\section{Metode Ta'lîl al-ahkâm pada Masa Sahabat}

a. Meniadakan hukuman karena alasan menolak mafsadah (kerusakan). ${ }^{13}$

Terdapat beberapa kasus yang dialami sahabat, yang mendapati nas tanpa penjelasan ilat hukum, dan mereka mencoba menta'lîl hukum tersebut. Salah satu contohnya adalah masalah hukum potong tangan pada saat bepergian.

Diriwayatkan dari Junadah ibn Abi Umayyah, bahwa kami bersama Busr ibn Artah berlayar di laut, kemudian ia dihadapkan pada seorang pencuri Bukhtitah (unta betina berleher panjang), bernama Misdar, kemudia Busr berkata: "Aku mendengar Rasulullah bersabda: "Tidak ada hukuman potong tangan pada saat bepergian." Seandainya tidak ada sabda tersebut, niscaya aku akan memotongnya." 14

Meskipun secara eksplisit, Rasulullah tidak menjelaskan ilat tidak diperbolehkannya potong tangan pada saat bepergian, tetapi secara implisit terkandung ilat, bahwa larangan tersebut mengandung maslahat dan menolak madarat.

b. Hukum yang mutlak atau mu'allal dengan suatu ilat, namun ternyata ilat tersebut sudah hilang atau hukum tersebut sudah berubah, maka mereka merubah hukum tersebut. ${ }^{15}$ Contoh dari kasus tersebut adalah seperti ta'lîl yang dilakukan sahabat tentang hukum salat wanita di masjid:

Diriwayatkan dari Abu Hurairah, bahwa Rasulullah saw bersabda: "Janganlah kalian melarang wanita untuk salat di masjid Allah, tetapi hendaknya mereka keluar tanpa memakai pewangi."

Diperbolehkannya wanita ke masjid, dengan syarat larangan memakai minyak wangi, menandakan adanya tindakan preventif

\footnotetext{
${ }^{12}$ Muhammad Musthafa Syalabi, Ta'ilil al-Ahkâm, 27.

${ }^{13}$ Ibid., 36.

${ }^{14}$ Abu Daud, Sunan, hadis no. 3828 dalam CD al-Kutub al-Tis'ah. Hadis ini adalah hadis shahîh.

${ }^{15}$ Muhammad Musthafa Syalabi, Ta'til al-Ahkâm, 37.

${ }^{16}$ Abu Daud, Sunan, hadis no. 478 dalam CD al-Kutub al-Tis'ah. Hadis ini adalah hadis shahîh.
} 
agar tidak menimbulkan mafsadah. Hal tersebut dikuatkan dengan hadis riwayat Abu Daud yang lain:

Diriwayatkan dari Ibn Umar bahwa Rasulullah saw bersabda: "Janganlah melarang istri kalian ke masjid, dan rumah mereka lebih baik bagi mereka." ${ }^{17}$

Setelah Rasulullah meninggal, zaman berubah dan wanitanya pun banyak mengalami perubahan, sehingga Aisyah berkata mengenai hal tersebut:

Diriwayatkan dari Aisyah r.a. bahwa ia berkata: "Jika Rasulullah saw mengetahui apa yang dilakukan wanit saat ini, maka beliau pasti akan melarang wanita (ke masjid) sebagaimana dilarangnya wanita Bani Israil. ${ }^{18}$

Dari pernyataan Aisyah tersebut diketahui, bahwa dibutuhkan perubahan dalam hukum wanita bepergian ke masjid, karena adanya mafsadah, jika hukum tersebut tetap dilaksanakan. ${ }^{19}$

c. Pekerjaan yang diperintahkan Allah di dalam kitabNya dan dilaksanakan oleh Rasulullah, tetapi para sahabat tidak melaksanakannya pada beberapa kesempatan, padahal mereka mengetahui perintah tersebut, karena adanya mafsadah apabila pekerjaan tersebut tetap dilaksanakan. ${ }^{20}$

Hal tersebut seperti yang dilakukan Umar ibn al-Khattab, yang melarang seorang muslim menikahi wanita dari ahli kitab, padahal Aquran menghalalkannya dalam firman Allah swt dalam Al-Qur'an, 5:5:

Pada hari ini dihalalkan bagimu yang baik. Makanan (sembelihan) orang yang diberi al-Kitab itu halal bagimu, dan makanan kamu halal (pula) bagi mereka. Dan (Dihalalkan mangawini) wanita yang menjaga kehormatan diantara wanita yang beriman dan wanita yang menjaga kehormatan di antara orang yang diberi alKitab sebelum kamu, bila kamu telah membayar mas kawin mereka dengan maksud menikahinya, tidak dengan maksud berzina dan tidak (pula) menjadikannya gundik. Barangsiapa yang

\footnotetext{
${ }^{17}$ Abu Daud, Sunan, hadis no. 480 dalam CD al-Kutub al-Tis'ah. Hadis ini adalah hadis shahîh.

${ }^{18}$ Abu Daud, Sunan, hadis no. 822 dalam CD al-Kutub al-Tis'ah. Hadis mauqûf dengan sanad muttasil sampai Aisyah r.a.

${ }^{19}$ Muhammad Musthafa Syalabi, Ta'îil al-Ahkâm, 39.

${ }^{20}$ Ibid., 43.
} 
kafir sesudah beriman (tidak menerima hukum Islam), maka hapuslah amalannya dan ia di hari kiamat termasuk orang yang merugi.

Diriwayatkan bahwa Hudhaifah menikahi wanita Yahudi, maka Umar menyuruhnya untuk menceraikannya. Hudhaifah menanyakan apakah hal tersebut hukumnya haram? Maka Umar menjawab: "Tidak, tetapi aku khawatir jika kalian melakukannya maka kalian akan menerima kehinaan dari mereka". Secara tidak langsung, larangan Umar untuk menikahi wanita ahli alKitab tersebut dikarenakan adanya bahaya, jika hal tersebut tetap dilakukan. Di antaranya, adanya percampuran nasab yang kurang bagus, pertumbuhan akhlak anak yang kurang Islami, dan adanya kekhawatiran para suami muslim akan mengikuti agama istrinya, atau bahkan mereka lebih memilih orang ahli kitab, dan lebih membiarkan para wanita muslimah hidup tanpa bersuami. ${ }^{21}$

d. Hukum yang belum ditetapkan pada zaman Rasulullah, para sahabat menetapkannya demi menolak mafsadah, meskipun perbuatan tersebut menyebabkan takhshîsh al-nash atau bertentangan dengan zâhir al-nash, ${ }^{22}$ seperti yang dilakukan Umar yang menjadikan talak tiga kali dalam satu majelis berarti terjadi tiga kali talak. Hal tersebut bertentangan dengan masa Rasulullah dan Abu Bakr, yang menghukumi talak tiga kali dalam satu majelis, dihitung satu kali talak.

Diriwayatkan dari Ibn Abbas bahwa talak pada masa Rasulullah saw, khalifah Abu Bakr dan dua tahun masa khilafah Umar ibn alKhattab, talak tiga kali (dalam satu majelis) dihitung satu talak. Kemudian Umar berkata: "Sesungguhnya manusia terburu-buru dalam perkara (talak), yang seharusnya mereka berhati-hati dalam hal tersebut. Seandainya kami jalankan ketentuan tersebut (yaitu talak tiga dalam satu lafadh berlaku talak tiga), niscaya mereka akan lebih berhati-hati". Lalu ia ('Umar) pun memberlakukan hal itu pada mereka. ${ }^{23}$

\footnotetext{
${ }^{21}$ Muhammad Musthafa Syalabi, Ta'îil al-Ahkâm, 44.

22 lbid., 56.

${ }^{23}$ Muslim, Shahîh, hadis no. 2689 dalam CD al-Kutub al-Tis'ah. Hadis ini adalah hadis shahîh.
} 
Tindakan Umar tersebut tentunya karena ada unsur maslahah yang diharapkan dari adanya pemberlakuan talak tersebut. ${ }^{24}$

e. Para sahabat mengerjakan pekerjaan yang tidak dikerjakan pada masa Rasulullah, dengan alasan kebaikan, dan melaksanakan hukum yang baru beralasan adanya kesamaan ilat yang manshûsh, ${ }^{25}$ seperti pengumpulan mushaf al-Qur'an pada masa khalifah Abu Bakr alSiddiq berdasarkan usulan Umar ibn al-Khattab. ${ }^{26}$

f. Para sahabat menetapkan hukum berdasarkan nas yang ada, tanpa mencari ilat hukum, tetapi mencela sahabat yang mempertanyakan alasan hukum tersebut. ${ }^{27}$

Dari 'Asim dari Mu'adhah berkata "Aku bertanya kepada 'Aisyah, bagaimana dengan wanita haid yang mengqadha' puasa dan tidak mengqada' salat?' 'Aisyah bertanya "Apakah kamu wanita Haruriyyah?” aku menjawab "Aku bukan dari Haruriyyah, namun hanya bertanya" 'Aisyah menjawab "Dulu kami dikenai hal tersebut. bahwa kami disuruh mengqadha' puasa dan tidak disuruh mengqadha' salat." ${ }^{28}$

Dari tanya jawab antara Asiyah dan wanita tersebut, diketahui bahwa Aisyah menjawab sesuai dengan jawaban Rasulullah tanpa mampu menjelaskan ilat dari hukum tersebut, namun pertanyaan wanita tersebut tentang alasan kenapa ada perbedaan dalam mengqadha' puasa dan salat bagi wanita haid, dijawab dengan pertanyaan Aisyah, apakah kamu wanita Haruriyyah yaitu wanita Iraq? Pertanyaan Aisyah tersebut wajar, karena penduduk Iraq terkenal dengan rasionya. ${ }^{29}$

\section{Metode Ta'lîl al-ahkâm pada Masa Tâbi'în dan Tâbi' Tâbi'în}

a. Hukum yang terkandung dalam nas bersifat mutlak atau umum, jika hukum yang mutlak atau umum tersebut dilaksanakan, maka akan bertentangan dengan kemaslahatan, maka mereka mendahulukan

\footnotetext{
${ }^{24}$ Muhammad Musthafa Syalabi, Tâîil al-Ahkâm, 58.

25 lbid., 64.

26 lbid., 64.

27 lbid., 69.

${ }^{28}$ Muslim, Shahîh, hadis no. 508 dalam CD al-Kutub al-Tis'ah. Hadis ini adalah hadis shahîh.

${ }^{29}$ Muhammad Musthafa Syalabi, Tâîl al-Ahkâm, 70.
} 
maslahat, meskipun dengan cara mentaqyîd al-nash, atau takhshîsh, atau meninggalkan zâhir al-nash.

Diriwayatkan dari Mujahid dari Ibn Umar, bahwa Rasulullah saw bersabda: "izinkanlah para wanita untuk pergi ke masjid pada malam hari. ${ }^{\text {"30 }}$

Menurut Waqid, ketika kondisi tidak aman dia melarang wanita keluar masjid pada malam hari, karena akan menimbulkan kerusakan yang lebih besar. ${ }^{31}$

b. Hukum yang tidak ada nashnya tetapi mereka menetapkan hukum berdasarkan maslahat, yang dalam istilah ulama ushûl disebut metode maslahah mursalah. Seperti yang diriwayatkan oleh al-Kindi, bahwa Abd al-Rahman ibn Hubairah al-Akbar tidak menahan harta orang yang safih, ${ }^{32}$ tetapi ia mengumumkan kepada khalayak tentang kesafihan orang tersebut, dan melarang orang lain untuk berinteraksi dengannya, tetapi ia menetapkan hartanya tetap dipegang oleh orang safih tersebut. Keputusan Abd al-Rahman tersebut mengandung kbaikan bagi si safih dan masyarakat sekitarnya, karena mereka akan berhati-hati ketika berinteraksi dengannya, dan diharapkan jika si safih merasa dijauhi masyarakat, ia akan kembali sadar. ${ }^{33}$

c. Pekerjaan yang mubah atau sunnah ditinggalkan, karena jika dikerjakan akan mendatangkan mafsadah, seperti yang dilakukan Alqamah ibn Qais dan Amru ibn Sharhabil, yang tidak ingin diumumkan kematiannya kepada orang lain. Hal tersebut berbeda dengan tradisi para sahabat sebelumnya yang kematiannya diumumkan kepada masyarakat. Alqamah ibn Qais dan Amru ibn Sharhabil tidak ingin diumumkan kematiannya, karena dikhawatirkan seperti kembali ke masa Jahiliyyah atau orang lain akan mengikutinya dengan tindakan yang berlebihan, sehingga menyerupai masa Jahiliyyah. ${ }^{34}$

\footnotetext{
${ }^{30}$ Al-Bukhari, Shahîh, hadis no. 848 dalam CD al-Kutub al-Tis'ah. Hadis ini adalah hadis shahîh.

${ }^{31}$ Muhammad Musthafa Syalabi, Ta'îl al-Ahkâm, 74 .

${ }^{32}$ Gila, bodoh, atau pemboros.

${ }^{33}$ Ibid., 86.

${ }^{34}$ Ibid., 88.
} 


\section{Metode Ta'lîl al-Ahkâm pada Masa Ulama Ushûl}

Pada masa Rasulullah hingga masa Tâbi" Tâbi'în, proses ta'lîl menggunakan metode yang sederhana, namun pada masa perkembangan ilmu ushûl hingga saat ini, ta'lîl menjadi tema perdebatan di kalangan ulama ushûl, ${ }^{35}$ karena itu di bawah ini dibahas tentang pandangan ulama ushûl tentang pengertian ilat.

Ilat menurut bahasa berarti al-maradh, yaitu penyakit. Arti ilat diambil dari al-maradh, karena pengaruh ilat terhadap hukum sama dengan pengaruh penyakit pada seseorang. Apabila dikatakan si fulan ber-ilat, maka berarti si fulan berubah dari sehat menjadi sakit. ${ }^{36}$

Ilat dalam istilah ulama ushûl, tidak sama rumusannya yang mungkin disebabkan perbedaan sudut pandang teologis atau dari sudut pandang esensi dan fungsi qiyâs. ${ }^{37} \mathrm{Di}$ antara definisi yang dikemukakan ulama ushûl adalah:

1. Menurut Mu'tazilah, ilat adalah: Washf (sifat) yang dengan sendirinya berpengaruh kepada adanya hukum. ${ }^{38}$

2. Menurut al-Ghazali, ilat adalah: Washf (sifat) yang berpengaruh terhadap adanya hukum, dengan sebab ditetapkan Allah. ${ }^{39}$

3. Menurut Fakhruddin al-Razi, ilat adalah: Washf (sifat) yang memberitahukan adanya hukum. ${ }^{40}$

4. Menurut Abd al-Wahhab Khalaf, ilat adalah washf(sifat) pada dasar (ashl) yang di atasnya dibangun suatu hukum, sehingga dengan washf tersebut dapat diketahui adanya hukum pada furû' (cabang). ${ }^{41}$

5. Menurut Abu Zahrah, ilat ialah pokok yang menjadi landasan qiyâs. ${ }^{42}$

Dari beberapa definisi di atas dapat diketahui bahwa ilat adalah sesuatu/sifat yang ada pada asal yang menjadi landasan atau sebab adanya hukum, dan dengan adanya sifat itulah diketahui adanya hukum pada cabang.

\footnotetext{
35 lbid., 94.

${ }^{36}$ Wahbah al-Zuhaili, Ushûl al-Fiqh al-Islâmi, juz I (Damaskus: Dar al-Fikr, 1986), 646.

37 Sulaiman Abdullah, Dinamika Qiyâs dalam Pembaharuan Hukum Islam (Jakarta: Pedoman Ilmu Jaya, 1996), 132.

${ }^{38}$ Wahbah Zuhaili, Ushûl al-Fiqh al-Islâmi, 646.

39 Ibid.

${ }^{40}$ Sulaiman Abdullah, Dinamika Qiyâs dalam Pembaharuan Hukum Islam, 133.

41 'Abd al-Wahhab Khalaf, IIm Ushûl al-Fiqh (Beirut: Dar al-'Ilm, t.t.), 63.

${ }^{42}$ Muhammad Abu Zahrah, Ushûl al-Fiqh (Beirut: Dar al-Fikr al-Arabi, t.t), 237.
} 
Dalam kehujjahan ilat, para ulama ushûl berbeda pendapat. Orang yang mengakui ilat dalam nash, berarti ia mengakui adanya qiyâs. Menurut Abu Zahrah, dalam masalah ini ulama terbagi menjadi tiga golongan:

1. Golongan pertama (mazhab Hanafi dan Jumhur) berpendapat, bahwa nash hukum pasti memiliki ilat. Selanjutnya mereka mengatakan:"Sesungguhnya sumber hukum asal adalah ilat hukum itu sendiri, hingga ada petunjuk (dalil) yang menentukan lain."

2. Golongan kedua beranggapan sebaliknya, bahwa nash hukum itu tidak berilat, kecuali ada dalil yang menentukan adanya ilat.

3. Golongan ketiga ialah ulama yang menentang qiyâs yang menganggap tidak adanya ilat hukum. ${ }^{43}$

Ulama ushûl berbeda pendapat tentang syarat yang harus diperhatikan dalam ilat. ${ }^{44}$ Menurut Abu Zahrah ada lima syarat pokok dalam ilat, yaitu:

1) Ilat harus merupakan sifat yang jelas dan tampak, sehingga ia menjadi sesuatu yang menentukan. ${ }^{45}$ Tanpa diketahui dengan jelas adanya ilat, kita tidak bisa melakukan qiyâs, seperti sifat memabukkan yang dapat diketahui dengan panca indra pada khamar, dapat diketahui pula dengan panca indra pada barang lain yang memabukkan. Contoh ilat yang tidak jelas adalah sifat kerelaan dalam perserikatan. Kerelaan adalah dasar daripada perserikatan, akan tetapi karena kerelaan sesuatu hal yang sifatnya tidak zâhir, maka kerelaan tidak bisa menjadi ilat, yang menjadi ilat adanya perpindahan milik yang merupakan sesuatu hal yang nyata adalah ijab dan qabul. ${ }^{46}$

2) Ilat harus kuat, tidak terpengaruh oleh perubahan individu, situasi maupun keadaan lingkungan, dengan satu pengertian yang dapat mengakomodasi seluruh perubahan yang terjadi secara definitif.

\footnotetext{
43 Ibid.

${ }^{44}$ Menurut al-Zuhaili, ulama ushûl mensyaratkan dua puluh empat syarat dalam ilat, di antaranya ada yang bersepakat di dalamnya dan adapula syarat yang diperselisihkan. Menurutnya, dari dua puluh empat syarat tersebut ada enam syarat pokok yang harus diperhatikan dalam ilat. Abd alWahhab Khallaf mengemukakan empat syarat ilat, dan menurut Abu Zahrah ada lima syarat yang harus diperhatikan dalam ilat. Lihat Wahbah Zuhaili, Ushûl al-Fiqh al-Islâmi, 652. Abdul Wahhab Khalaf, Ilm Ushûl al-Fiqh, 63-70. Muhammad Abu Zahrah, Ushûl al-Fiqh 366-368.

${ }^{45}$ Muhammad Abu Zahrah, Ushûl al-Fiqh, 367.

46 A. Djazuli dan Nurol Aen, Ushul Fiqh Metodologi Hukum Islam (Jakarta: PT RajaGrafindo Persada, 2000), 139.
} 
'Memabukkan' adalah ilat diharamkannya khamar, dengan suatu anggapan bahwa khamar sendiri, biasanya memang memabukkan. Jadi 'memabukkan' itu sifat yang tetap pada khamar. Apabila dalam situasi tertentu, ternyata khamar tidak memabukkan, itu hanyalah kasus khusus yang tidak bisa menggeser sifat aslinya. ${ }^{47}$

3) Harus ada korelasi (hubungan yang sesuai) antara hukum dengan sifat yang menjadi ilat. 'Pembunuhan' merupakan ilat untuk terhalangnya hak kewarisan, sebab dasar hukum kewarisan adalah unsur hubungan yang mengaitkan anatra pihak pewaris dengan pihak yang diwarisi. 'Pembunuhan' jelas memutuskan hubungan tersebut.

4) Sifat yang menjadi ilat yang kemudian melahirkan qiyâs harus berjangkauan luas (muta'addi), tidak terbatas hanya pada satu hukum tertentu. Misalnya, bepergian yang membolehkan berbuka dan wajib qadha' sejumlah hari yang ditinggalkannya pada hari yang lain, hanyalah ilat yang terbatas pada bulan Ramadan. Oleh karena itu, 'bepergian' tidak tepat dijadikan alasan sebagai ilat dibolehkannya meninggalkan salat.

5) Sifat yang menjadi ilat itu tidak dinyatakan batal oleh suatu dalil. Apabila sifat itu bertentangan dengan nash, maka hal tersebut tidak patut menjadikannya sebagai dasar qiyâs. ${ }^{48}$

Dalam menentukan ilat, ulama ushûl membahasnya dalam bab masalik ilat. Masalik ilat ialah cara untuk mengetahui ilat, atau dengan ungkapan yang lebih lengkap ialah cara untuk mengetahui hal yang dianggap oleh Shari' (Allah) sebagai ilat dan yang tidak diangggap sebagai ilat. ${ }^{49}$ Menurut al-Khudhari Bik, masâlik Ilat adalah cara menetapkan ilat. ${ }^{50}$ Dalam pengkajian ilat, tidak cukup hanya menemukan sifat yang munasib untuk dijadikan ilat hukum, tetapi harus ada dalil yang mendukungnya ${ }^{51}$.

Menurut al-Syaukani, masâlik ilat adalah cara yang menunjukkan tentang ilat. ${ }^{52}$ Menurutnya, dalam melakukan qiyâs tidak cukup hanya dengan adanya persamaan dalam ashl dan far' saja, tetapi harus ada dalil

\footnotetext{
${ }^{47}$ Muhammad Abu Zahrah, Ushûl al-Figh, 367.

48 Ibid., 367-370.

49 Ibid., 373.

${ }^{50}$ Muhammad al-Khudari Bik, Ushûl al-Fiqh (Mesir: Maktabah al-Tijariyyah al-Kubra, 1969), 325.

51 Ibid.

${ }^{52}$ Al-Syaukani, Irsyâd al-Fuhûl ilâ Tahqî̀ al-Haq min 'ilm al-Ushûl(Beirut: Dar al-Fikr, t.t), 210.
} 
yang menunjukkan ilat tersebut yang terdiri dari nash, ijmâ', dan istinbâth, maka dari itu dibutuhkan masalik ilat. ${ }^{53}$

Para ulama berselisih tentang jumlah masâlik ilat, al-Syaukani dalam kitabnya, Irsyâd al-Fuhûl, menjelaskan bahwa ada sebelas cara menentukan ilat, yaitu: ijmâ', nash, îmâ' wa al-tanbîh, al-istidlâl alâ illiyah al-hukm bi fi'l al-nabi, al-sabr wa al-taqsîm, al-munâsabah, althard, al-daurân, tanqîh al-manâth, dan tahqîq al-manâth. ${ }^{54}$

Menurut al-Zuhaili ada sembilan cara untuk dapat mengetahui ilat, yaitu, al-nash, al-ijmâ', al-îmâ', al-sabr wa al-taqsîm, al-munâsabah, al-syibh, al-thard, al-daurân, dan tanqîh al-manâtht. ${ }^{55}$ Menurut alKhudari Bik, ${ }^{56}$ Abu Zahrah" ${ }^{57}$ dan Abd al-Wahhab Khallaf ${ }^{58}$ di antara tujuh cara tersebut ada tiga cara yang masyhur untuk mengetahui ilat hukum yaitu dengan melalui nash, ijmâ' dan as-sabr wa taqsîm. Karena perbedaan pembagian masâlik ilat di atas, maka di bawah ini dijelaskan tiga masâlik ilat yang disepakati ulama:

1. Dengan nash

Menurut Abd al-Wahhab Khalaf, ilat yang ditujukan oleh nash adakalanya sharîh (jelas) dan adakalanya dengan isyarah. Yang dimaksud dengan nash yang sharîh ialah lafaz nash yang menunjukkan ilat dengan menempatkannya secara lughawi ${ }^{59}$, yaitu dengan memperhatikan kata yang digunakannya, seperti kata: لأجل dalam ayat tersebut di bawah ini:

a. Al-Qur'an:59: 7.

(Mereka Kami utus) selaku rasul pembawa berita gembira dan pemberi peringatan agar supaya tidak alasan bagi manusia membantah Allah sesudah diutusnya rasul itu.

b. Hadis nabi

Supaya harta itu jangan hanya beredar di antara orang kaya saja di antara kamu ${ }^{60}$.

c. Hadis Nabi Muhammad saw:

${ }^{53} \mathrm{lbid}$.

${ }^{54} \mathrm{lbid}$.

${ }^{55}$ Wahbah al-Zuhaili, Ushûl al-Figh al-Islâmi, 661.

${ }^{56}$ Muhammad al-Khudari Bik, Ushûl al-Figh, 325.

${ }^{57}$ Muhammad Abu Zahrah, Ushûl al-Figh, 374.

${ }^{58}$ Abdul Wahhab Khalaf, 'IIm Ushûl al-Fiqh, 75.

${ }^{59}$ Ibid., 88.

${ }^{60} \mathrm{Al}-\mathrm{Qur}$ 'an:59: 7. 
Rasulullah saw bersabda: "Saya hanya mencegah kamu menyimpan daging kurban karena ada yang berkumpul membutuhkannya, maka makanlah, bersedekahlah dengannya, dan simpanlah". ${ }^{1}$

Hadis tersebut menggambarkan bahwa selama masih ada manusia yang membutuhkan makanan, maka tidak sah menyimpan makanan itu. Tidak boleh menyimpan suatu makanan selama disekeliling kamu masih ada fakir miskin yang membutuhkan makanan itu.

Apabila kata yang menunjukkan ilat bisa pula dipastikan bukan ilat, maka nilainya zanni, seperti dalam ayat Al-Qur'an: 17,78.: Dirikanlah salat dari sesudah matahari tergelincir.

Adapun yang ilatnya dengan isyarah seperti dalam hadis Nabi saw: Rasulullah saw bersabda: "Tidaklah pembunuh itu mewarisi sesuatu" $" 62$

Menurut al-Khudari Bik, menetapkan ilat dengan nas terbagi menjadi dua yaitu sharîh (jelas) dan ghair sharîh (tidak jelas). Nash yang sharîh terbagi menjadi beberapa tingkatan, yaitu:

a. Lafaz yang memang ditujukan untuk ilat dan tidak mengandung arti lainnya, seperti kata: لعلة كذا (untuk ilat ini), لأجل كذا (untuk tujuan ini), كي يكون (agar supaya), dan إذن يكون كذا (maka untuk ini).63

b. Lafaz zâhir yang menunjukkan tentang ilat tetapi masih mengandung arti lain, seperti:

$$
\text { اللاح, الباء, إن الثرطية, أن الناصبة, و إن و أن الناصبتان .64 }
$$

c. Lafaz yang tidak langsung menunjukkan tentang ilat tetapi ada hal lain yang menjelaskannya seperti: الفاء الداخلة على الوصف (huruf fa' yang masuk dalam kata sifat). ${ }^{65}$

d. Lafaz seperti di atas tetapi diucapkan oleh râwi bukan oleh syari' ${ }^{66}$

Nash ghair sharîh adalah lafaz yang disampaikan dengan peringatan dan tersembunyi (tanbîh dan îmâ). Salah satu contoh dari îmâ' adalah hadis:

\footnotetext{
${ }^{61}$ Abu Daud, Sunan, hadis no. 2429 dalam CD al-Kutub al-Tis'ah, hadis shahîh.

${ }^{62}$ Abu Daud, Sunan, hadis no. 3955 dalam CD al-Kutub al-Tis'ah, hadis shahîh.

${ }^{63}$ Muhammad Al-Khudari Bik, Ushûl al-Figh, 325.

${ }^{64} \mathrm{lbid}$.

${ }^{65} \mathrm{Ibid} ., 326$.

${ }^{66} \mathrm{lbid}$.
} 
Diriwayatkan dari Abd al-Malik ibn Umair, saya mendengar Abd al-Rahman ibn Abi Bakrah berkata: "Abu Bakrah menulis sirat ke anaknya yang di Sijistan, janganlah kamu menghukumi dua orang yang bersengketa ketika kamu sedang marah, karena aku mendengar Nabi saw bersabda: Tidak boleh seorang hakim menghakimi dua orang, ketika ia sedang marah" ${ }^{37}$

Dipahami dari hadis ini bahwa terdapat ilat yang tersembunyi yaitu الغضب (marah). ${ }^{68}$

Al-Syaukani membagi menentukan ilat dengan nas ini menjadi dua yaitu qathi' (sharîh), seperti lafaz:

$$
\text { لعلة كذا, أو لمؤثر كذا, أو لموجب كذا, أو لأجل كذا. }
$$

dan ghair qath'i, yang menurut al-Syaukani hanya ada tiga lafaz yaitu:

1. اللام

2. الباء

3. إنها من الطو افين : seperti hadis Nabi

Sedangkan îmầ dan tanbîh yang menurut al-Khudari merupakan bagian dari nas, al-Syaukani menjadikannya terpisah menjadi maslak illah tersediri. Menurut al-Syaukani, îmâ' dan tanbih adalah lafaz yang menyebutkan sifat tetapi tidak menunjukkan apakah itu untuk ilat atau tidak. Dalam cara ini ada beberapa hal, yaitu:

a. Menyebut hukum atas ilat dengan huruf (الفاء) , seperti firman Allah dalam Al-Qur'an, 5:38.:

Laki-laki yang mencuri dan perempuan yang mencuri, potonglah tangan keduanya.

b. Shari' menyebutkan hukum dengan sifat, jika sifat itu bukan ilat, maka akan hilang faidah dari tujuan hukum tersebut, seperti perkataan seseorang yang menghadap Rasulullah:

Diriwayatkan dari Abu Hurairah ra, bahwa datang seorang lelaki kepada Rasulullah dan berkata: "Celakalah aku", Rasulullah bertanya: Kenapa? Lelaki tersebut menjawab: "aku menggauli istriku pada bulan Ramadan", Rasulullah bersabda: "bebaskanlah hamba sahaya", lelaki tersebut menjawab: "saya tidak mempunyai

\footnotetext{
${ }^{67}$ Al-Tirmidhi, Sunan, hadis no 1254 dalam CD al-Kutub al-Tis'ah. Hadis shahîh. 68 Ibid.
} 
hamba sahaya" Rasulullah bersabda: "berpuasalah dua bulan berturut-turut", lelaki tersebut menjawab: "Aku tidak mampu", Rasulullah bersabda: berilah makan 60 orang miskin, lelaki tersebut menjawab: "aku tidak punya", maka nabi mengambil kantong berisi kurma dan berkata: Siapakah yang bertanya? Lelaki tersebut menjawab: "saya" Rasul bersabda:" Bersedekahlah dengan kurma ini" lelaki tersebut berkata: "apakah ada orang lain yang lebih membutuhkan daripada kami ya Rasulullah? Demi yang mengutusmu dengan kebenaran, tidak ada yang membutuhkan dari ahli bait kecuali kami" rasul pun tertawa, sehingga terlihat gigi taringnya, lalu berkata: "Kalau begitu, ini untuk kalian" ${ }^{69}$

Dari hadis tersebut diketahui bahwa ilat diwajibkannya kafarat dengan membebaskan budak, atau berpuasa dua bulan berturutturut, atau memberi 60 orang miskin adalah adanya hubungan suami istri pada siang hari di bulan Ramadan.

c. Adanya sifat yang membedakan dua hukum, sebagaimana sabda Rasulullah:

Dari ibn Umar ra berkata, Rasulullah membagi harta rampasan pada pengan Khaibar, untuk penunggang kuda mendapat dua bagian dan untuk pejalan kaki mendapat satu bagian

Yang membedakan bagian tersebut adalah dari ketentuan sifat yang ada, yaitu antara penunggang kuda dan pejalan kaki.

d. Mengikat hukum dengan ism musytaq maka ta'lîq tersebut adalah maksud dari ilat hukum. Seperti perkataan: أكرم زيدا العالم (muliakan Zaid yang alim) maka kata alim merupakan ilat dari adanya ikram.

e. Adanya hukum dan sifat disertai dengan syarat dan pahala. Seperti firman Allah dalam Al-Qur'an, 65:2.:

Barangsiapa bertakwa kepada Allah, niscaya Dia akan mengadakan baginya jalan keluar.

f. Ta'lîl ketiadaan hukum jika terdapat mâni' (penghalang). Seperti firman Allah dalam Al-Qur'an, 41:44.:

Dan Jikalau Kami jadikan al-Qur'an itu suatu bacaan dalam bahasa selain Arab, tentulah mereka mengatakan: "Mengapa tidak dijelaskan ayat-ayatnya?"

\footnotetext{
${ }^{69}$ Al-Bukhari, Shahîh, hadis no. 4949 dalam CD al-Kutub al-Tis'ah. Hadis shahîh.
} 
g. Allah mengingkari orang yang berpendapat bahwa Allah menciptakan segala sesuatu tanpa faidah atau hikmah, sebagaimana firmanNya dalam Al-Qur'an, 23: 115.:

Maka apakah kamu mengira, bahwa sesungguhnya Kami menciptakan kamu secara main-main (saja), dan bahwa kamu tidak akan dikembalikan kepada kami?

2. Dengan ijmâ'

Menurut jumhur ulama ushûl, apabila ijmak itu qath'i dan sampainya kepada kita juga qath'i dan adanya ilat di dalam cabang juga demikian, serta tidak ada dalil yang menentangnya, maka hukumannya pun qath'i. Apabila tidak demikian halnya, hukumnya pun bernilai zanni. ${ }^{70}$

Menurut al-Syaukani, ijmak dalam maslak illah ini terbagi menjadi dua yaitu: a. Ijmak untuk ilat yang sudah ditentukan. Seperti menentukan wilayah harta dengan ilat al-shughr (masih kecil).b. ijmak terhadap dasar/dalil ta'lîl (mencari/menentukan ilat). ${ }^{71}$

Contoh ilat yang diketahui dengan melalui ijmak seperti mendahulukan saudara lelaki seibu sebapak daripada saudara lelaki sebapak di dalam warisan karena ada talian kekerabatan ibu. Dengan qiyâs pula didahulukan anak paman seibu sebapak dari anak paman yang sebapak, anak saudara laki-laki seibu sebapak dari anak saudara laki-laki sebapak. Dengan qiyâs pula didahulukan saudara laki-laki seibu sebapak dari saudara sebapak, di dalam perwalian. Dengan demikian, dalam ijmak itu secara implisit terkandung ilat dan menetapkan sebagai ilat hukum, dan dengan ilat ini hukum menjadi meluas. ${ }^{72}$

3. Dengan al-Sabr wa al-taqsîm

Yaitu dengan cara meneliti dan mencari ilat yang paling tepat di antara beberapa kemungkinan ilat. Ini adalah pekerjaan seorang mujtahid di dalam memilih mana yang paling tepat menjadi ilat. Untuk mengetahui ilat semacam ini sudah tentu diperlukan suatu pemahaman yang mendalam baik tentang sistem Hukum Islam

\footnotetext{
${ }^{70}$ Ibid., 150 dan Muhammad al-Khudari Bik., Usul al-Fiqh, 325.

${ }^{71}$ Al-Syaukani, Irsyâd al-Fuhûl, 150.

${ }^{72}$ Muhammad Abu Zahrah, Usul al-Fiqh, 377.
} 
secara keseluruhan dan maksud syarak maupun perinciannya di samping diperlukan ketajaman berpikir. ${ }^{73}$

Al-Syaukani berpendapat bahwa al-Sabr wa al-taqsîm dalam bahasa berarti al-ikhtibâr (meneliti/menguji). Dinamakan dengan alSabr wa al-taqsîm, karena dalam menentukan ilat semua sifat diteliti dan diuji kecocokannya untuk dijadikan ilat hukum. Dalam istilah, ia mengandung dua arti, yaitu: a. Yang berkisar antara nafyu dan itsbat disebut juga al-munhashir yaitu membatasi sifat yang ada di dalam maqîs 'alaih, kemudian diuji dalam maqîs dan mengeluarkan sifat yang tidak cocok dengannya dan mengambil satu sifat yang cocok untuk dijadikan ilat hukum. b. Al-Muntasyir yaitu yang tidak berkisar antara nafyu dan itsbat. ${ }^{74}$

Menurut al-Khudari, al-sabr wa al-taqsîm adalah membatasi sifat yang menunjukkan ilat dengan mengeluarkan sifat yang tidak cocok dan menentukan salah satu untuk dijadikan ilat. Seperti dalam menentukan ilat diharamkannya riba dalam gandum yang mengandung beberapa ilat yaitu karena rasa atau karena ia makanan, atau karena ukuran/timbangan. Dari tiga hal tersebut yang paling cocok dijadikan ilat adalah karena rasa. ${ }^{75}$

Menurutnya, penentuan ilat dengan al-sabr wa al-taqsîm ini ada beberapa cara, yaitu:

a. Menghilangkan sifat yang dihapus.

b. Menjelaskan bahwa sifat yang hendak dihapus adalah tard.

c. Dalam sifat yang dihapuskan tidak terdapat munâsabah (korelasi) ${ }^{76}$

d. Al-Daurân, yaitu sifat yang menjadikan hukum itu ada dengan keberadaannya. ${ }^{77}$

Muhammad Abu Zahrah mengatakan bahwa pencarian ilat dengan al-sabr wa al-taqsîm ini ada tiga proses, yaitu:

1. Takhrîj al-manâth

\footnotetext{
${ }^{73}$ A. Jazuli dan Nurol Aen, Ushul Fiqh Metodologi Hukum Islam, 135.

${ }^{74}$ Al-Syaukani, Irsyâd al-Fuhûl, 213-214.

${ }^{75}$ Muhammad al-Khudari Bik, Ushûl al-Figh, 325.

${ }^{76}$ Ibid., 327-328.

${ }^{77}$ Menurut al-Syaukani, al-daurân adalah menentukan keberadaan hukum dengan adanya sifat dan ketiadaan hukum dengan tiadanya sifat tersebut. Seperti sifat 'memabukkan' yang menjadi ilat diharamkannya khamr yang dikiaskan dengan minuman lainnya. Jika dalam juice tersebut terdapat sifat 'memabukkan' maka ia menjadi haram namun jika tidak ada sifat 'memabukkan' maka ia tidak haram.
} 
Yaitu usaha menemukan sifat yang pantas menjadi ilat hukum. Hal ini dilakukan, apabila nas hukum tidak menjelaskan ilat baik secara ungkapan langsung, isyarat atau tanda dan tidak ada ijma para ulama tentang ilat tersebut. ${ }^{78}$

Contoh takhrîj al-manâth di dalam hal ini, seperti pembunuhan yang diancam dengan sanksi qisas adalah pembunuhan sengaja dengan menggunakan alat-alat yang biasanya mematikan manusia, maka diqiyaskan kepada alat ini segala alat yang bisa mematikan, baik digunakan pada masa Rasulullah ataupun tidak digunakan.

2. Tanqîh al-manâth

Yaitu mengenali sifat yang terkandung dalam hukum, lalu memilih salah satu sifat yang paling tepat dan patut dijadikan ilat hukum, sedangkan sifat yang kurang berhubungan disingkirkan. Dengan demikian mujtahid menetapkan satu sifat saja sebagai ilat hukum. ${ }^{79}$

Contoh tanqîh al-manâth, seperti orang yang membatalkan puasa Ramadan dengan ijmak diancam dengan sanksi: (1) membebaskan budak, apabila tidak sanggup atau tidak ada; (2) harus puasa dua bulan berturut-turut dan apabila tidak sanggup puasa, harus; (3) memberikan makan sebanyak 60 orang miskin.

Dalam hubungan ini, timbul pertanyaan apakah ilatnya karena mengadakan hubungan kelamin pada bulan Ramadan atau karena membatalkan puasanya sendiri. Pada zatnya, melakukan hubungan kelamin dengan isterinya sendiri adalah boleh. Oleh karena itu, ilatnya adalah karena merusak kemuliaan bulan Ramadan, dan di dalam hal ini jelas bahwa membatalkan puasa dengan sengaja adalah sebab adanya sanksi tadi.

3. Tahqîq al-manâth

Tahqîq al-manâth yaitu meneliti apakah sifat yang sudah diketahui unsurnya itu terdapat dalam kasus yang sesuai dan tercakup dalam keumuman pengertiannya. ${ }^{80}$

\footnotetext{
${ }^{78}$ Muhammad Abu Zahrah, Ushûl al-Fiqh, 378.

${ }^{79} \mathrm{lbid} ., 378$.

${ }^{80}$ Ibid., 379.
} 
Contoh tahqîq al-manâth, telah disepakati bahwa memabukkan adalah ilat dari minuman yang haram, akan tetapi penerapan di dalam minuman yang memabukkan yang bermacammacam membutuhkan ijtihad ahli. Demikian pula persaksian, akan tetapi keadaan seorang itu adil dan tidak adil ditentukan atas dasar ijtihad.

Al-Syaukani berpendapat bahwa selain tiga cara yang disebutkan di atas (al-nash, ijmâ', dan al-sabr wa al-taqsîm) dalam menetukan ilat hukum, ada beberapa masâlik al-illah yang lain, yaitu:

1. Mencari dalil atas ilat hukum dengan bersandarkan pada fi'l Nabi Muhammad saw. Seperti perbuatan Nabi ketika bersujud karena sahwi (lupa), maka diketahui dari perbuatan sujud Nabi tersebut adalah karena lupa. Maka lupa merupakan ilat dari sujud sahwi.

2. Al-Munâsabah, yaitu menentukan ilat dengan adanya munasabah (korelasi) tanpa ada yang menolak dari munasabah tersebut. Dalam munasib ini, al-Syaukani membagi menjadi dua yaitu haqî́iy dan iqnâ'iy. Yang haqîqi terbagi menjadi tiga, yaitu: dharûriy ${ }^{81}$, hâjiy ${ }^{82}$, dan tahsîniy. ${ }^{83}$

Menurut sebagian ulama ushûl, Dalam hal munâsib ini ada empat macam ilat:

\footnotetext{
${ }^{81}$ Yang dimaksud dengan dharûriy adalah sesuatu yang harus ada demi kemaslahatan agama dan dunia, dalam arti apabila hal yang dharûriy ini tidak bisa diwujudkan, tata kehidupan manusia tidak akan mantap bahkan kacau dan menimbulkan kemafsadatan. Dengan demikian, dijaga dari segala hal yang merusaknya. Hal yang dharûriy ini ada lima: Memelihara agama, memelihara diri dan meningkatkan nilai-nilai kejiwaan, memelihara kehormatan keluarga dan pembinaan generasi, memelihara harta.

82 Yang dimaksud dengan hâjiy adalah mewujudkan segala hal yang memudahkan dan meringankan manusia di dalam memikul tugas hidupnya, apabila tidak ada yang hajiyat, menyebabkan kesukaran, kesulitan dan kesempitan, akan tetapi tidak sampai ke tingkat kemafsadatan umum. Termasuk hajiyyat ini aturan yang berhubungan dengan masalah rukhsah, lupa, kesalahan, terpaksa dan dipaksa, bay' al-mu'aththah, bay' salam, seperti juga dijelaskan dalam al-Qur'an: "Allah hendak meringankan (keberatan) dari kamu, karena manusia itu diciptakan bersifat lemah"

${ }^{83}$ Yang dimaksud dengan kamaliyat atau tahsiniyyat adalah hal yang mewujudkan kesempurnaan dan kebaikan hidup yang hakikatnya kembali kepada akhlak yang luhur dan mulia serta kebiasaaan pergaulan yang terpuji. Aturan yang berkaitan dengan kamaliyat dan tahsiniyyat ini antara lain shalat sunnah dan puasa sunnat, cara makan dan minum, dilarang melihat, mendengar yang tidak baik, menutup aurat, adab dan sopan santun pergaulan, hal yang najis, dan lain-lain: Allah SWT menegaskan: "Allah tidak hendak menyulitkan kamu, tetapi Dia hendak membersihkan kamu dan menyempurnakan nikmat-Nya bagimu, supaya kamu bersyukur". Al-Qur'an, 5:6.
} 
a. Al-munâsib al-muatstsir (Korelasi yang bersifat mengikat), yaitu munasib yang ditunjukkan oleh syarak bahwa itulah ilat hukum dan hukum adalah atharnya. Oleh karena itu, disebut al- munâsib almuatstsir, ini tidak lain adalah ilat yang di-nas-kan. ${ }^{84}$ Menurut Abu Zahrah, al- munâsib al-muatstsir adalah hubungan antara sifat dengan hukum yang ditentukan oleh syarak ${ }^{85}$.

Contoh dari bagian ini adalah 'anak kecil' yang ditetapkan menjadi sebab wajibnya perwalian terhadap harta bendanya. Hukum demikian telah ditetapkan oleh syari' dalam nash hukum seperti yang dinyatakan dalam al-Qur'an:

Dan ujilah anak yatim itu sampai mereka cukup umur untuk kawin. Kemudian jika menurut pendapatmu mereka telah cerdas (pandai memelihara harta), maka serahkanlah kepada mereka harta-hartanya. ${ }^{86}$

Ilat yang memiliki munasabah bentuk pertama ini merupakan ilat hukum terkuat dibanding ilat hukum lainnya karena langsung ditunjuk oleh dalil syarak. ${ }^{87}$ Al-munasib al-mulaim (korelasi yang sesuai), ialah munasib yang tidak di'i'tibarkan syarak dengan zatnya, akan tetapi ada dalil lain baik nas atau ijmak yang menunjukkan bahwa munasib tersebut adalah ilat hukum ${ }^{88}$. Dengan arti lain yaitu hubungan hukum ilat yang tidak mendapatkan pengukuhan langsung dari Allah sebagai ilat hukum, tetapi ada pentunjuk dari nas atau ijmak yang menganggap ilat hukum itu sebagai penentu dari hukum sejenis. ${ }^{89}$

b. Al-Munasib al-mulgha, yaitu wasf yang menjelaskan bahwa dalam membina hukum perlu dimantapkan kemaslahatan, namun ada dalil shar'i yang membatalkannya. ${ }^{90}$ Menurut A. Jazuli, al-munasib almulgha ialah sesuatu yang sepintas lalu menimbulkan persangkaan bahwa hal tersebut menimbulkan hikmah akan tetapi ternyata ada dalil syarak bahwa munasib tersebut tidak diakui syarak dan dilarang

\footnotetext{
${ }^{84}$ A. Djazuli dan Nurol Aen, Ushul Figh Metodologi Hukum Islam, 142.

${ }^{85}$ Muhammad Abu Zahrah, Ushûl al-Figh, 370.

${ }^{86}$ Al-Qur'an, 4:6.

${ }^{87}$ Ibid., 371.

${ }^{88}$ A. Djazuli dan Nurol Aen, Ushul Fiqh Metodologi Hukum Islam, 143.

${ }^{89}$ Muhammad Abu Zahrah, Ushûl al-Fiqh, 371.

${ }^{90}$ Abdul Wahhab Khalaf, Ilm Ushûl al-Fiqh, 87.
} 
syarak, seperti mempersamakan hak laki-laki dan anak perempuan di dalam warisan, ${ }^{91}$ secara zahir, ini adalah hal yang munasabah, akan tetapi ditolak oleh syariat dengan firmanNya dalam Al-Qur'an, 4:11.: Allah mensyari'atkan bagimu tentang (pembagian pusaka untuk) anakmu. Yaitu: bahagian seorang anak lelaki sama dengan bahagian dua orang anak perempuan.

c. Al-munasib al-mursal (korelasi yang lepas), yaitu sesuatu yang jelas bagi mujtahid bahwa menetapkan hukum azasnya mewujudkan kemaslahatan akan tetapi tidak ada dalil yang menunjukkan secara terperinci bahwa syara melarang atau membolehkannya, inilah yang di kalangan para ahli ushûl disebut dengan maslahah mursalah, contoh dalam hal ini seperti tidak sah akad nikah pernikahan kecuali apabila umur si pengantin wanita 16 tahun dan si pengantin pria 18 tahun. $^{92}$

Dalam masalah al-munasib al-mursal ini para ulama berselisih akan kehujjahannya. Mazhab Maliki dan Hanbali mangambil munasabah ini sebagai hujjah hukum, yang dikenal dengan sebutan maslahah mursalah sedangkan mazhab al-Shafi'i dan Hanafi tidak mempergunakan munasabah ini sebagai hujjah hukum. ${ }^{93}$

Dari pengertian ulama ushûl tentang ilat, syarat dan masaliknya, Shalabi menyimpulkan bahwa tidak diragukan lagi bahwa ilat adalah sifat yang mengandung hikmah, jika hukum diterapkan karena ilat tersebut, maka akan mencapai tujuan yaitu mendapat maslahat. ${ }^{94}$

\section{Simpulan}

Ta'lîl al-ahkâm adalah menjelaskan dan cara menemukan ilat hukum. Terdapat beberapa cara dalam ta'lîl ahkam dari masa Rasulullah hingga ulama ushûl.

Pada masa Rasulullah, Ta'lîl terdapat pada Al-Qur'an dan hadis, di antaranya; 1. Ilat menyatu dengan sifat hukum, 2. Menyebutkan hukum beserta sebabnya. 3. Menjelaskan perintah diiringi dengan lafadz tafdhîl, 4. Menjelaskan hukum beserta ilatnya

\footnotetext{
${ }^{91}$ A. Djazuli dan Nurol Aen, Ushul Fiqh Metodologi Hukum Islam, 144.

92 lbid.

${ }^{93}$ Muhammad Abu Zahrah, Ushûl al-Figh, 373.

${ }^{94}$ Muhammad Musthafa Syalabi, Ta'lîl al-Ahkâm, 127.
} 
yang ditandai dengan huruf ta'lîl, 5. Menjelaskan hukum disertai dengan penjelasan maslahatnya, atau sebaliknya.

Metode ta'lîl al-ahkâm pada masa Sahabat: 1. Meniadakan hukuman karena alasan menolak mafsadah, 2. Hukum menjadi berubah, karena ilatnya telah hilang. 3. Tidak melaksanakan perintah Allah dan RasulNya, karena adanya mafsadah apabila pekerjaan tersebut tetap dilaksanakan. 4. Menetapkan hukum yang belum ditetapkan Rasulullah demi menolak mafsadah, 5. Mengerjakan pekerjaan yang tidak dikerjakan pada masa Rasulullah, dengan alasan kebaikan, 6. Menetapkan hukum berdasarkan nas yang ada tanpa mencari ilat hukum.

Metode ta'lîl al-ahkâm pada masa Tâbi în dan Tâbi' Tâbi'în: 1. Mendahuluan maslahat, jika hukum yang terkandung dalam nas bersifat mutlak atau umum bertentangan dengan kemaslahatan, 2 . Menggunakan metode maslahah mursalah. 3. Meninggalkan pekerjaan yang mubah atau sunnah, karena jika dikerjakan akan mendatangkan mafsadah.

Metode ta'lîl al-ahkâm pada masa Ulama Ushûl: Dengan nash, ijmâ', dan al-sabr wa al-taqsîm.

\section{Daftar Rujukan}

Abdullah, Sulaiman. Dinamika Qiyâs dalam Pembaharuan Hukum Islam. Jakarta: Pedoman Ilmu Jaya, 1996.

Al-Syaukani. Irsyâd al-Fuhûl ilâ Tahqî̀ al-Haq min ilm al-Ushûl. Beirut: Dar al-Fikr, t.t.

al-Zuhaili, Wahbah. Ushûl al-Fiqh al-Islâmiy. Damaskus: Dar al-Fikr, tt. Bik, Muhammad Al-Khudari. Ushûl al-Fiqh. Mesir: Maktabah alTijariyyah al-Kubra, 1969.

CD al-Kutub al-Tis'ah.

Djazuli, A. dan Nurol Aen. Ushûl Fiqh Metodologi Hukum Islam. Jakarta: PT RajaGrafindo Persada, 2000.

Khalaf, 'Abd al-Wahhab. Ilm Ushûl al-Fiqh. Beirut: Dar al-'Ilm, t.t. Syalabi, Muhammad Musthafa. Ta'lîl al-Ahkâm. Beirut: Dar alNahdhah al-Arabiyyah, 1981.

Zahrah, Muhammad Abu. Ushûl al-Fiqh. Beirut: Dar al-Fikr al-Arabi, t.t. 